\title{
Security and Legal Protection for Building Owner of the Land Belongs to Others Related to Principle of Horizontal Separation
}

\author{
${ }^{1}$ Rr. Dijan Widijowati, ${ }^{2}$ Aristyo Rahadiyan \\ 1,2Jayabaya University, Jakarta, Indonesia \\ Email: turiz_diyan00@yahoo.com
}

\begin{abstract}
The increasing need for land can lead to conflicts in the land sector; therefore, the Indonesian government has enacted Law Number 5 of 1960 concerning Basic Agrarian Principles, which intends to establish a National Agrarian Law based on Customary Law on land. The Land Law adopted by the Basic Agrarian Law rests on Customary Law which recognizes the horizontal scheiding principle. The implementation is with the existence of lease rights for buildings. In line with the principle of horizontal separation adhered to by the Basic Agrarian Law, building construction can be carried out either on one's land or on other people's land. The problem discussed in this study is how legal certainty and protection for building owners who stand on land owned by other people and what legal remedies the building owner can take to own the building still use other people's land. The research method used is normative juridical; typology used in this research is explanatory research and prescriptive research. The approach used in this research is normative. Based on this research results, Defendant I and Defendant II are not allowed to submit a petition for vacant buildings belonging to Plaintiff is on land owned by Defendant I and Defendant II. The building belonged to Plaintiff, so Defendant I and Defendant II did not have authority over the building. If it is related to the principle of horizontal separation, the request to vacate the establishment is contrary to the regulation adhered to by agrarian law in Indonesia. Can do another result of the efforts made by building owners to use other people's land through non-litigation, litigation, and abrasive actions.
\end{abstract}

Keywords: Legal Certainty, Legal Protection, Horizontal Separation Principle.

\section{A. INTRODUCTION}

The land has an essential meaning for humans because land, besides having social value, also has economic value. A land is a place for humans to live and continue their life. Ter Haar explained that land has an essential meaning for human life because humans live (Asikin, 2012). The land also provides energy and livelihood for humans, and for some humans, land is a burial place. For indigenous peoples, there is a magical, religious relationship between humans and land. The land is a fundamental human need. The land is one of the main elements in human life and a natural wealth source, a crucial development for Indonesia (Atikah, 2019). A land is a place where humans live their lives and get resources to continue their lives; therefore, the human need for land remains excellent (Gray, 1991). The role of land in national development to meet various needs is also increasing, both as housing, offices, education, business, etc. In this regard, the need for legal certainty in the land sector will also increase. Land that humans need often results in land 
disputes; therefore, legal rules must regulate humans and land's relationship (Harsono, 2020).

The land is a vital element in the nation's life and state because it is a source of justice and prosperity for the community. The relationship between the Indonesian country and the land is eternal (Kansil, 2006). Giving guarantees of legal certainty in the land sector requires the availability of written, complete, and precise legal instruments. Land and buildings are basic human needs that affect the existence of each individual. Land rights have an essential role in human life. The more people there are, the more advanced the community is, the more influential land rights' position will be (Krishna \& Qaim, 2017).

The need for land is increasing, along with increased other requirements related to land (Marella, 2017). Land can be used as collateral to obtain loans, either from banks or various other financial institutions. Land can be used as collateral for both buying and selling, leasing, and other purposes. Land has a crucial role; therefore, legal certainty is demanded regarding land (Markus, 2015). To obtain legal guarantees of legal certainty for land, a written, complete, transparent, and consistent legal instrument is required under the spirit and content of the applicable provisions (Muljadi \& Gunawan, 2004).

The Basic Agrarian Law intends to establish a National Agrarian Law based on Customary Law on land (Parlindungan, 1984). The birth of the Basic Agrarian Law creates uniformity regarding Land Law so that there are no more land rights according to western law and land rights according to customary law (Rizky \& Hutapea, 2021). The main objectives of the Basic Agrarian Law are:

1. Laying the foundations for the formulation of national agrarian law as a tool to bring prosperity, happiness, and justice to the state and people to achieve a just and prosperous society.

2. Laying the foundations for unity and simplicity in the land law.

3. Laying the groundwork to provide legal certainty regarding land rights for the people as a whole (Rubaie, 2007).

The Basic Agrarian Law regulates land rights given to people or owned either alone or jointly with other people or legal entities (Ruggie, 2011). The right to land, when viewed from its origin, can be divided into two, namely: Primary Land rights, namely land rights that are primary are rights to land originating from state land; and Land rights that are secondary, namely land rights that are secondary, are rights to land arising from a land of other parties (Sangsun, 2007).

Based on the fundamental principles stipulated in the Basic Agrarian Law, land rights are born whose designation is differentiated based on the type of use as well as the legal persons who are the owners, namely as follows:

1. Property rights, which are the fullest and strongest and hereditary rights, are only granted to single Indonesian citizens, except for certain legal entities whose utilization can be adjusted to the designation of their land in the area where the land is located. 
2. The right to cultivate is the right to exploit land that is directly controlled by the state for a particular time, which can be given to either a single Indonesian citizen or an Indonesian legal entity (which is established under Indonesian law and domiciled in Indonesia).

3. The right to build is the right to develop and own a building on land that is not his own, for a particular time, which can be owned by either a single Indonesian citizen or an Indonesian legal entity (established in Indonesia according to Indonesian law and domiciled in Indonesia).

4. The right to use is the right to use or collect products from land owned by other people or directly controlled by the state, which is not a lease or land management, which can be granted for a particular time to single Indonesian citizens or Indonesian legal entities, foreigners who are domiciled in Indonesia as well as foreign legal entities that have representatives in Indonesia (Santoso, 2005).

The explanation of the Basic Agrarian Law states that the Right to Use is a collection of definitions of rights known in Agrarian Law with various names which all have differences in each region, and in the context of simplification, in the Basic Agrarian Law for land rights used one word, namely the Right to Use (Saragih, 1996).

The Land Law adopted by the Basic Agrarian Law rests on Customary Law which recognizes the horizontal scheiding principle (Siahaan, 2003). Based on the principle of horizontal separation, land rights do not automatically include ownership of buildings and plants on them (Soekanto, 2015). If the legal action is intended to include buildings and plants on it, this must be clearly stated in the deed, proving the legal act in question has been carried out. In practice, a legal action regarding land can include buildings and plants on it, but it must meet the following requirements (Soeroso, 2011). First, the building and the plant are physically an integral part of the land concerned, meaning that the building has a foundation, and the plant is difficult planting (Supriadi, 2017). Second, the facilities and plants belong to the person owning the land. Third, the meaning is explicitly stated in the deed, proving the legal act in question has been committed (Susyanti, 2010).

The problem raised by researchers in this study is how legal certainty and protection for building owners stand on others' land. What are the legal measures that can be taken by building owners so that they can still hold the building using other people's land?

\section{B. METHOD}

The form of research in this research is normative juridical, a form of research to find data through library materials. The research typology used in this research is explanatory research and prescriptive research. The descriptive study aims to describe or explain a symptom, while rigorous research aims to provide suggestions or solutions to a problem. The approach used in this research is the normative 
approach or statutory approach, which is carried out by examining all laws and regulations relating to legal certainty and protection for owners of buildings on land owned by others related to the principle of horizontal separation. The legal materials examined in this research are primary legal materials, secondary legal materials, and tertiary legal materials.

The technical analysis of legal materials in this study uses qualitative data analysis techniques, namely explaining the relationship between facts and law: first, primary legal materials are analyzed by interpreting legal science, such as authentic interpretation, grammatical interpretation, and systematic interpretation. Second, secondary legal materials were analyzed by content analysis of library materials used in this study. Third, systematics and construction are carried out to conclude.

\section{RESULT AND DISCUSSION}

\section{Legal certainty and protection for building owners who stand on land owned by other people}

Sudikno Mertokusumo argues that legal certainty guarantees that the law is carried out in an exemplary manner. Legal certainty requires efforts to regulate the law in-laws and regulations made by an authorized and authoritative party. These rules have a juridical aspect that can guarantee legal certainty that the law functions as a regulation that must be obeyed (Sutedi, 2019).

Meanwhile, according to Jan Michael Otto, legal certainty is defined as the possibility that in a specific situation:

a. The availability of clear, consistent, and easy-to-obtain rules, issued by and recognized because of the state's power.

b. The ruling (government) agencies apply these legal rules consistently and are also subject to and obedient.

c. Citizens, in principle, adapt their behaviour to these rules.

d. The judges (judiciary) are independent and consistently apply these legal rules when resolving legal disputes.

e. Concrete judicial decisions are implemented.

Indonesia is a constitutional state. This means that all state life must be based on law. For the rule of law concept to be implemented, there are two things that the Indonesian state must strive for, namely protection of the law and law enforcement. Philips M. Hadjon argues that legal protection protects dignity and recognition of human rights possessed by legal subjects based on applicable legal provisions. This means that legal protection is carried out using lawful means to preserve human rights' dignity and honour included by every legal subject (Wijaya, 2013).

During the court examination, both the Plaintiffs and Defendants I and II were the legal owners of $240 \mathrm{~m} 2$ (two hundred and forty square meters) of building and land, respectively. Can see this from the primary mastery of each of these property rights, namely:

a. Plaintiff owns the title to the building. Plaintiff obtained the building by purchasing from Faris as stated in the house sale and purchase agreement and 
the transfer of rental rights numbers 86 and 87 dated November 28, 1959, made in Lim Tong Kie, Notary, Jakarta. The Plaintiff, in this case, has been paying rent from 1959 to 2005 (the onset of this dispute).

b. Land ownership rights are owned by Defendant I and Defendant II. Defendant, I and Defendant II obtained ownership rights to land through a sale and purchased with the late Lie Kian Hong's heir before Office of the Land Act Maker as stated in the Sale and Purchase Deed No. Number 67 dated February 6, 1961.

Based on this, we can see that the basis for the control of Plaintiff, Defendant I, and Defendant II over their respective rights is under national law provisions.

\section{Legal Efforts That Building Owners Can do to Remain Able to Own Buildings by Using Land Owned by Others}

Ownership of land, including buildings on it, is a fundamental unit in ownership of land rights. This is due to the national land law system, which adheres to the principle of horizontal separation. Thus, ownership of land and buildings on land can result in differences in ownership rights. I can see this in the transfer of title to land in Mangga Besar I/62, RT 007/RW 008, Mangga Besar Village, Tamansari District, and West Jakarta ownership. The building is physically owned and controlled by the Plaintiff. In contrast, the land is legally owned by Defendant I and Defendant II 9 (Zhang, 2008).

Differences in ownership of land and building rights can lead to very complex disputes. To protect the parties' interests, it is necessary to make regulatory efforts to guarantee justice and legal certainty. Can make efforts that building owners can make to use other people's land through:

First, we can do it with Non-Litigation Efforts, namely:

a. Discussion

The best option is to conduct deliberations to reach a consensus. The deliberations' results are stated by agreeing with the landowner and the building to determine what the current rental price for the land is. Concerning the case in this study, the building owner as a tenant must pay rent to Defendant I and Defendant II, who are the rightful landowners. The agreement should be made with an authentic deed so that it can serve as solid evidence. The arrangements made include: First, the Lease Agreement to Rent. Based on the provisions in Article 1548 of the Civil Code, a lease is an agreement whereby one party binds himself to give the other party the enjoyment of an item for a time. Certain and by payment of a price by which the latter party is willing to pay. A lease is a consensual agreement, meaning that the deal is already binding and binding when the contract is reached on its main elements, namely goods and prices.

One party should deliver the goods to be enjoyed by the other party, while the last party should pay rent. So goods are handed over not to be owned as buying and selling but only for use and enjoyment. Thus, the delivery only has the character of handing over power over the rented goods. 
Second, the agreement grants usufructuary rights over freehold land, namely by giving usufructuary rights over the ground with a deed made by the Official for Making Land Deeds (PPAT) and granted for a maximum period of 25 (twenty-five) years and cannot be extended but can be renewed by giving new use rights. This agreement must be registered in the land book at the land office and binds the third party from registration.

b. The building owner bought the land

In connection with the case in this research, the Plaintiff can buy land from Defendant I and Defendant II through a sale and purchase process in front of the Official for Making Land Deeds. Sale and purchase are reciprocal agreements in which one party promises to give up title to an item. In contrast, the other party promises to pay the price consisting of an amount of money to acquire the title.

c. The landowner can compensate the building owner as compensation for the building owner's costs to acquire its rights.

Second, we can do it through litigation. If the amicable settlement by deliberation is not successful, the parties can resolve the dispute through a court which is a legal remedy. Then thirdly, efforts can be made with Arbitrage and Alternative Dispute Resolution. Land tenure can be carried out with building use rights, usage rights, lease rights or hitchhiking rights. If the constructing party controls the land with building use rights, then based on the provisions of Government Regulation Number 24 of 1997 concerning Land Registration, a certificate may be issued as proof. By knowing that the right to build is the right to construct and own a building on land owned by another party, by registering the right to use the building, according to Government Regulation Number 24 of 1997 concerning Land Registration, a third party is deemed to know that the building belongs to the first party.

Applying the law in building ownership on land owned by others is that everyone who wants to construct a building must own land with a clear ownership status. However, if that person does not own land, then he can build on land owned by another person as long as the condition has already obtained approval and land use permit from the land bag right holder in the form of a written agreement. The written agreement must contain the parties' rights and obligations, area, location, land boundaries; building function; and land use period.

\section{CONCLUSION}

The existence of Law Number 5 of 1960 concerning Basic Agrarian Regulations has ended the dualism of land law instruments that were in effect before and has been replaced by a national land law system based on the philosophy of customary law. Thus, the articles in Law Number 51960 concerning Basic Agrarian Regulations incarnate customary law. Therefore can conclude that Indonesia adheres to the principle of horizontal separation.

The principle related to building ownership used in the prevailing law is the principle of customary law, namely: 1). Whereas in principle, there is a separation 
between land and buildings standing on it (horizontal separation principle) which states that the law that applies to land does not automatically apply to buildings standing on it. 2). Whereas the right of ownership over land does not automatically cover the existing buildings on it. In customary law, it is stipulated that the building owner is the owner of the building.

There are two types of mili rights on the disputed land, namely property rights to facilities owned by A (Plaintiff) and Freehold Rights to Land owned by B and C (Defendants I and II). During the court examination, both the Plaintiffs and Defendants I and II were the legal owners of $240 \mathrm{~m} 2$ (two hundred and forty square meters) of building and land, respectively.

\section{REFERENCES}

1. Asikin, Z. (2012). Pengantar Tata Hukum Indonesia. Jakarta: Rajagrafindo Persada.

2. Atikah, N. (2019). Pierre Cardin Trademark Dispute. Mulawarman Law Review, 14-28.

3. Gray, K. (1991). Property in thin air. The Cambridge Law Journal, 50(2), 252-307.

4. Harsono, B. (2020). Hukum Agraria Indonesia. Jakarta: Universitas Trisakti.

5. Kansil, C. S., \& Kansil, C. S. (2006). Modul Hukum Perdata Termasuk Asas-Asas Hukum Perdata. Jakarta. Pradnya Paramita.

6. Krishna, V. V., Kubitza, C., Pascual, U., \& Qaim, M. (2017). Land markets, property rights, and deforestation: insights from Indonesia. World Development, 99, 335-349.

7. Marella, M. R. (2017). The commons as a legal concept. Law and Critique, 28(1), 61-86.

8. Markus, S. (2015). Property, predation, and protection. Cambridge University Press.

9. Muljadi, K., \& Gunawan, W. (2004). Hak-hak atas Tanah. Jakarta: Kencana.

10. National Land Agency. (2013). Performance Report of Government Agencies for Fiscal Year 2012. Jakarta: BPN RI.

11. Parlindungan, A. P. (1984). Serba serbi hukum agraria. Bandung: Alumni

12. Rizky, M., \& Hutapea, T. P. D. (2021). Legal Protection for Buyers Who Have A Good Letter in Purchase of Object Guarantee Based on Horizontal Separation Principles.

13. Rubaie, A. (2007). Hukum pengadaan tanah untuk kepentingan umum. Malang: Bayumedia.

14. Ruggie, J. (2011). Report of the secretary-general's special representative on the issue of human rights and transnational corporations and other business enterprises: Guiding principles on business and human rights: implementing the united nations' protect, respect and remedy framework. Netherlands Quarterly of Human Rights, 29(2), 224-253.

15. Sangsun, F. S. (2007). Tata Cara Mengurus Sertifikat Tanah. Jakarta: Visimedia.

16. Santoso, U. (2005). Hukum agraria dan hak-hak atas tanah. Jakarta: Prenada Media 
17. Saragih, D. (1996). Pengantar hukum adat Indonesia. Bandung:Tarsito.

18. Siahaan, M. P. (2003). Bea perolehan hak atas tanah dan bangunan: teori \& praktek. Depok: RajaGrafindo Persada.

19. Soekanto, S., \& Sri, M. (2015). Metode Penelitian dan Penulisan Hukum. Jakarta: Rajawali.

20. Soeroso, R. (2011). Pengantar Ilmu Hukum. Bandung: Bumi Aksara.

21. Supriadi. (2017). Hukum Agraria. Jakarta: Sinar Grafika.

22. Susyanti, N. S. (2010). Bank Tanah: Alternatif Penyelesaian Masalah Penyediaan Tanah Untuk Pembangunan Kota Berkelanjutan. Makasar: AS Publishing.

23. Sutedi, A. (2019). Peralihan hak atas tanah dan pendaftarannya. Jaarta: Sinar Grafika.

24. Wijaya, K. (2013). Perspektif Hukum Agraria Pada Masyarakat Indonesia. Jurnal Hukum Unsrat, 1(5), 38-54.

25. Zhang, M. (2008). From public to private: the newly enacted Chinese property law and property rights protection in China. Berkeley Bus. LJ, 5, 317. 